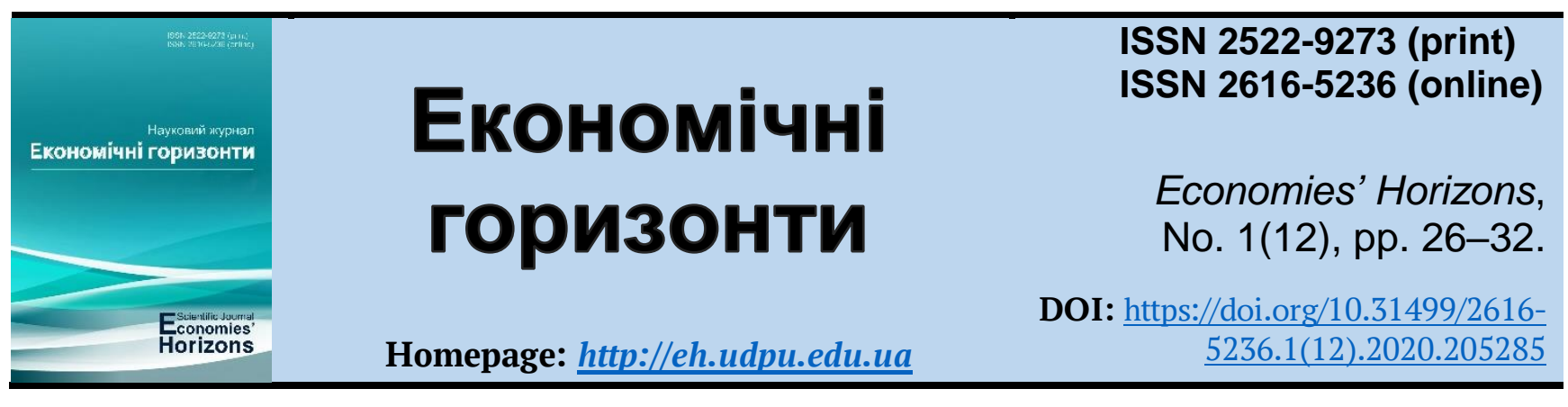

UDC 334.012.64(477)

\title{
Conceptual foundations of the development of business social responsibility in Ukraine
}

\author{
Taisiya H. Bondaruk ${ }^{1}$, Doc. Ec. Sc., Professor \\ Igor S. Bondaruk ${ }^{2}$, Cand. Ec. Sc., Associate Professor
}

Received: 26 January 2020

Accepted: 29 February 2020

\begin{abstract}
Bondaruk, T. H. and Bondaruk, I. S. (2020), "Conceptual foundations of the development of business social responsibility in Ukraine”, Economies' Horizons, no. 1(12), pp. 26-32. doi: https://doi.org/10.31499/2616-5236.1(12).2020.205285.
\end{abstract}

Abstract. Purpose of the research. The main purpose of the article is to deepen the theoretical foundations of business social responsibility formation and its development in Ukraine. Methodology. It was used the following methods: comparative economic analysis, induction and deduction, summarizing, logical generalization, grouping and graphic expression. Results. It is substantiated that the development of business, the integration of the Ukrainian economy into the world economic system poses new challenges to business, related to the intensification of processes in the field of social responsibility in Ukraine. It is substantiated that the management of social responsibility of business is realized through the influence of the state on the improvement of labor relations, the introduction of honest business practices, against-corruption practices, expanding environmental responsibility of business and its cooperation with local communities. It is determined that business social responsibility is gradually becoming an important component of strategic management of enterprises in Ukraine. It is proved that in modern conditions the partnership between the state and business (joint regulation) prevails, and also the development of self-regulation is intensified, which together are able to ensure their effectiveness in modern conditions. Practical meaning. Important trends in the development of business social responsibility in Ukraine are insufficient assessment of the importance of social responsibility, and compliance with only mandatory rules set by applicable law. Prospects for further research. The formation of theoretical foundations of business social responsibility and its development in Ukraine confirms the need for further scientific substantiation of toolkit for assessing the effectiveness of social responsibility.

Keywords: social responsibility of business, cooperation of business with local communities, joint regulation of social responsibility, self-regulation of social responsibility, ecological responsibility of business.

\section{JEL Classification: M21.}

Number of references: 10; number of tables: 0; number of figures: 1; number of formulas: $\mathbf{0 .}$

\footnotetext{
${ }^{1}$ National Academy of Statistics, Accounting and Audit; Head of the Department of Finances, Banking and Insurance; ORCID ID: https://orcid.org/0000-0001-9410-6428; e-mail: bondaruk23@ukr.net.

${ }^{2}$ Pavlo Tychyna Uman State Pedagogical University; Associate Professor at the Department of Marketing, Management and Business Management; ORCID ID: https://orcid.org/0000-0001-8960-7973; e-mail: bondarukigor@ukr.net.
} 
Концептуальні засади розвитку соціальної відповідальності бізнесу в Україні

\author{
Таїсія Григорівна Бондарук ${ }^{1}$, д. е. н., професор \\ Ігор Сергійович Бондарук ${ }^{2}$, к. е. н., доцент
}

Стаття надійила: 26.01.2020

Стаття прийнята: 29.02.2020
Bondaruk T. H., Bondaruk I.S. Conceptual foundations of the development of business social responsibility in Ukraine. Економічні горизонти. 2020. № 1(12). C. 26-32. DOI: 10.31499/2616-5236.1(12).2020.205285.

Анотація. Мета дослідження. Метою статті $є$ поглиблення теоретичних засад формування соціальної відповідальності бізнесу та їі розвитку в Україні. Методологія. У статті використано наступні методи дослідження: порівняльний економічний аналіз, системний аналіз, індукція та дедукція, логічне узагальнення, групування і графічний метод. Результати. Обгрунтовано, що розвиток бізнесу, інтеграція української економіки до світової економічної системи ставить перед бізнесом нові завдання, які пов’язані з активізацією процесів у сфері соціальної відповідальності в Україні. Обгрунтовано, що управління відносинами соціальної відповідальності бізнесу реалізується через вплив держави на вдосконалення трудових відносин, впровадження чесних бізнес-практик, антикорупційних практик, розширення екологічної відповідальності бізнесу та його співпраці з місцевими громадами. Визначено, що соціальна відповідальність бізнесу поступово стає важливою складовою стратегічного управління підприємствами в Україні. Встановлено, що в сучасних умовах переважають партнерські відносини держави та бізнесу (спільне регулювання), а також спостерігається активізація розвитку саморегулювання, що у сукупності здатні забезпечити свою результативність у сучасних умовах. Практичне значення. Важливими тенденціями у розвитку соціальної відповідальності бізнесу в Україні $є$ недостатня оцінка ступеня важливості соціальної відповідальності, та виконання лише обов'язкових, визначених чинним законодавством норм. Перспективи подальших досліджень. Формування теоретичних засад соціальної відповідальності бізнесу та їі розвитку в Україні підтверджує необхідність подальшого наукового обгрунтування інструментарію оцінювання ефективності соціальної відповідальності.

Ключові слова: соціальна відповідальність бізнесу, співпраця бізнесу з місцевими громадами, спільне регулювання соціальної відповідальності, саморегулювання соціальної відповідальності, екологічна відповідальність бізнесу.

Кількість джерел: 10; кількість таблиць: 0; кількість рисунків: 1; кількість формул: 0.

\section{Introduction.}

Today, the use of new effective tools for managing the sustainable development of society is becoming important. One of the effective tools for sustainable development of society is the implementation of the concept of business social responsibility, which involves not only the development of appropriate social strategy, but also contributes to socio-political stabilization in society. Business development, integration of the national economy into the world economic system poses new challenges to business, related to the intensification of processes in the field of social responsibility in

\footnotetext{
${ }^{1}$ Національна академія статистики, обліку та аудиту; завідувач кафедри фінансів, банківської справи та страхування; ідентифікатор ORCID: https://orcid.org/0000-0001-9410-6428; e-mail: bondaruk23@ukr.net.

2 Уманський державний педагогічний університет імені Павла Тичини; доцент кафедри маркетингу, менеджменту та управління бізнесом; ідентифікатор ORCID: https://orcid.org/0000-0001-8960-7973; e-mail: bondarukigor@ukr.net.
} 
Ukraine. In modern society, solving the problems of managing the development of business social responsibility is of primary importance.

\section{Literature review.}

Problems of development and functioning of business social responsibility were studied by F. Hayek (1967), M. Friedman (1970) and others. However, the state of theoretical developments of scientists in the field of creating conditions for business development today does not allow public authorities to effectively influence the processes of formation and development of social responsibility. The presented scientific results need to be generalized, taking into account new facts about the development of business social responsibility in Ukraine, as well as the trends of statehood and social-economic system of the country.

However, the solution of the problem of methodological support for the assessment of financial security of the state is unsystematic, multi-vector and insufficiently developed in the scientific literature, so it needs further research.

\section{Methods.}

The authors used the universal methods of scientific research (induction and deduction), as well as the method of analysis. The classification method was used by author too.

\section{Research objectives.}

The goal of the article is to deepen the theoretical foundations of the formation of business social responsibility and its development in Ukraine.

\section{Results and discussions.}

In modern conditions of the society development new requirements to formation of business social responsibility are put forward. The importance of tripartite interaction between the state, business and society is of primary importance. It necessitates the clarification of existing priorities, improvement of methods and tools for achieving strategic goals.

The formation of ideas of business social responsibility emerged in the 1970s in the USA and Great Britain (Komarova and Kovalchuk, 2016, p. 27) due to increasing public and consumer attention to the overall image of the company, in particular: the choice of honest and responsible business partners; ensuring social protection and non-discrimination of employees; product quality guarantee; the company's attitude to the environment and society; observance of transparency and openness, social responsibility in making strategic business decisions.

Existing models of business social responsibility have a multilevel structure. Researchers on business social responsibility distinguish three levels for determining social responsibility (Komarova and Kovalchuk, 2016, p. 27). The first (basic) level - the business pays taxes fully and legally, and the funds that come to the budget are distributed to the same social programs. The second (corporate) level - socially responsible business must pay an economically reasonable salary. The third (higher) level - socially responsible business should be engaged in charity on a voluntary basis.

At the international level, documents have been adopted that substantiate the philosophy of business social responsibility: Agreement on Social Policy, access to European Union law, 1991; Rio Declaration on Environment and Development (United Nations, 1992); UN Global Compact (New York, 2000); Millennium Development Goals (United Nations Millennium Declaration, 2000); International Standard "Guidance on Social Responsibility" (International Organization for Standardization, 2010); Sustainable Development Goals (United Nations, 2015) and others.

In Ukraine, the formation of ideas of business social responsibility began in 1996 by the Ukrainian Association of Quality and the Ukrainian Union of Industrialists and Entrepreneurs simultaneously with the implementation of the concepts of TQM (Total Quality Management) and model EFQM (European Foundation for Quality Management). TQM and EFQM stipulate that the company must satisfy all stakeholders, while demonstrating constant long-term care for consumers, its own 
staff and society, ensuring environmental protection, providing charitable activities and promoting sustainable development of society.

According to the Strategy for promoting the development of business social responsibility in Ukraine, business social responsibility is a conscientious attitude of business entities to the requirements of social necessity, social objectives, moral and ethical norms and values, understanding the consequences of their activities for society, state, consumers, business partners and their employees" (Socially responsible business. Ukraine, 2020). As mentioned in the Strategy, in accordance with European practice, business social responsibility extends to the following main areas: respect for human rights; compliance with legal requirements; business and corporate ethics; environmental protection; cooperation with stakeholders (employees, consumers), shareholders, community, business entities; compliance with international standards of conduct; transparency and accountability (Socially responsible business. Ukraine, 2020).

There are different approaches to the formation of business social responsibility. The most widespread approach is when social responsibility includes three components: economic - responsibility for the economic results of their activities and the impact on the economic results of stakeholders; environmental responsibility for the impact of economic activity on the environment; social - responsibility for solving social problems that arise as a result of economic activity of the company or in some way related to it.

Economic responsibility is based on the concept of justice, which states that the weal as a result of economic activity must be fairly distributed among the participants in economic relations, and all decisions will be made taking into account the requirements of honesty, fairness and openness. Economic responsibility involves honest business practices: setting fair prices; non-abuse of monopoly position; rejection of unfair methods of price and non-price competition; payment of fair remuneration to employees; conducting timely and complete settlements with contractors; transparency of activity; refusal to use corruption schemes, etc.

Environmental responsibility of business includes the obligation of decision-makers to implement actions aimed at protecting and improving the environment in general, and which also meet their own interests (Gunningham (ed.), 2009). Environmental responsibility is carried out in the following areas: environmental restriction of entrepreneurial activity; environmentally oriented business activities; environmental entrepreneurship. Environmental responsibility of business is understood as actions that benefit the environment (or reduce the negative impact of business on the environment), and go beyond what companies are required to do by law (Lee, 2012). Recently, the environmental component of business social responsibility has developed most dynamically, due to the presence of significant support from international organizations, national governments and local communities, as well as the high level of demand for environmentally friendly solutions in society.

Social responsibility includes the one for solving social problems that arise as a result of economic activity of business structures. The impact of business social responsibility on the effectiveness of the management system can be assessed not only in terms of the magnitude of the social effect for the enterprise and society in general, but also from the standpoint of economic effect, which will be manifested in the growth of enterprise activities in marketing, finance, management in general as well as in the improvement of financial indicators, reduction of operational risks, development of innovations and growth of labor productivity, and in creation of a stable business environment (Yuzyk, 2010).

Considering the processes of development of business social responsibility, we note the special role of the state in this development. Organizational and economic basis of the mechanism of development of business social responsibility is based on: state regulation, 
joint regulation and self-regulation of business social responsibility (Bondaruk, $T$. and Bondaruk, I., 2020). In state regulation, the state makes a direct regulatory influence on business for the formation of its social responsibility. The involvement of business in social responsibility is carried out through the regulatory policy of the state. The main tasks of the regulatory policy of business social responsibility are: ensuring the active participation of business entities in solving social-economic problems, the introduction of an innovative model of social responsibility; creating new jobs and reducing unemployment. In the combined regulation of business social responsibility, the state initiates the development of this responsibility, as well as regulatory policy in this sphere, which is consistent with business structures, while business social responsibility is carried out on the basis of state regulations and initiatives of business structures. In selfregulation, the state has no influence on the process of development of business social responsibility and the measures for directions in business social responsibility by business structures are developed by business structures independently (Bondaruk, T. and Bondaruk, I., 2020).

Current trends in the relationship between the state and business entities in the management of social responsibility tend to move from direct regulatory influence of the state on business to form its social responsibility to the development of partnerships based on the interest of both government and business in such interaction. The state will gradually move away from the role of the main initiator of increasing the business social responsibility and the practice of direct regulation of such responsibility, and business structures will consciously take an active position to expand the social responsibility of entrepreneurial activity.

As a result of the analysis of different types of relations between the state and business in the process of development of its social responsibility, it is established that in modern conditions the partnership relations of the state and business prevail (combined regulation), there is also an intensification of the development of self-regulation, which together are able to ensure their effectiveness in modern conditions.

We consider that today Ukraine has not yet formed its own model of business social responsibility. Thus, the results of a survey of enterprises on the need to provide social responsibility revealed that only half of respondents $(53.3 \%)$ support the idea of implementing a social responsibility policy, $41.1 \%$ - do not consider it necessary, and $5.6 \%$ of companies said that they do not see any point in introducing such a practice. Almost a third of native companies stated that they do not implement social responsibility measures and for most of them these measures are not relevant due to lack of funds. One in ten companies believes that this function belongs to the state, but not business. And only $29.6 \%$ of enterprises have their own social responsibility strategy $\left(\mathrm{Ko}^{-}\right.$ valenko, 2016).

According to the study of social responsibility, which was aimed at identifying the main trends, barriers and prospects for the development of corporate social responsibility in Ukraine - business social responsibility has not yet become a part of organizational management in companies. Only half of the companies that implement business social responsibility policies have a social responsibility strategy, a quarter of companies have a budget for implementing social responsibility programs, and in most companies the leadership are looking for ideas for business social responsibility programs and developing plans for their implementation.

The most common practices of implementing business social responsibility in Ukraine are: labor practices, against-corruption practices, environmental responsibility, honest business practices, cooperation with local communities (Figure 1). 


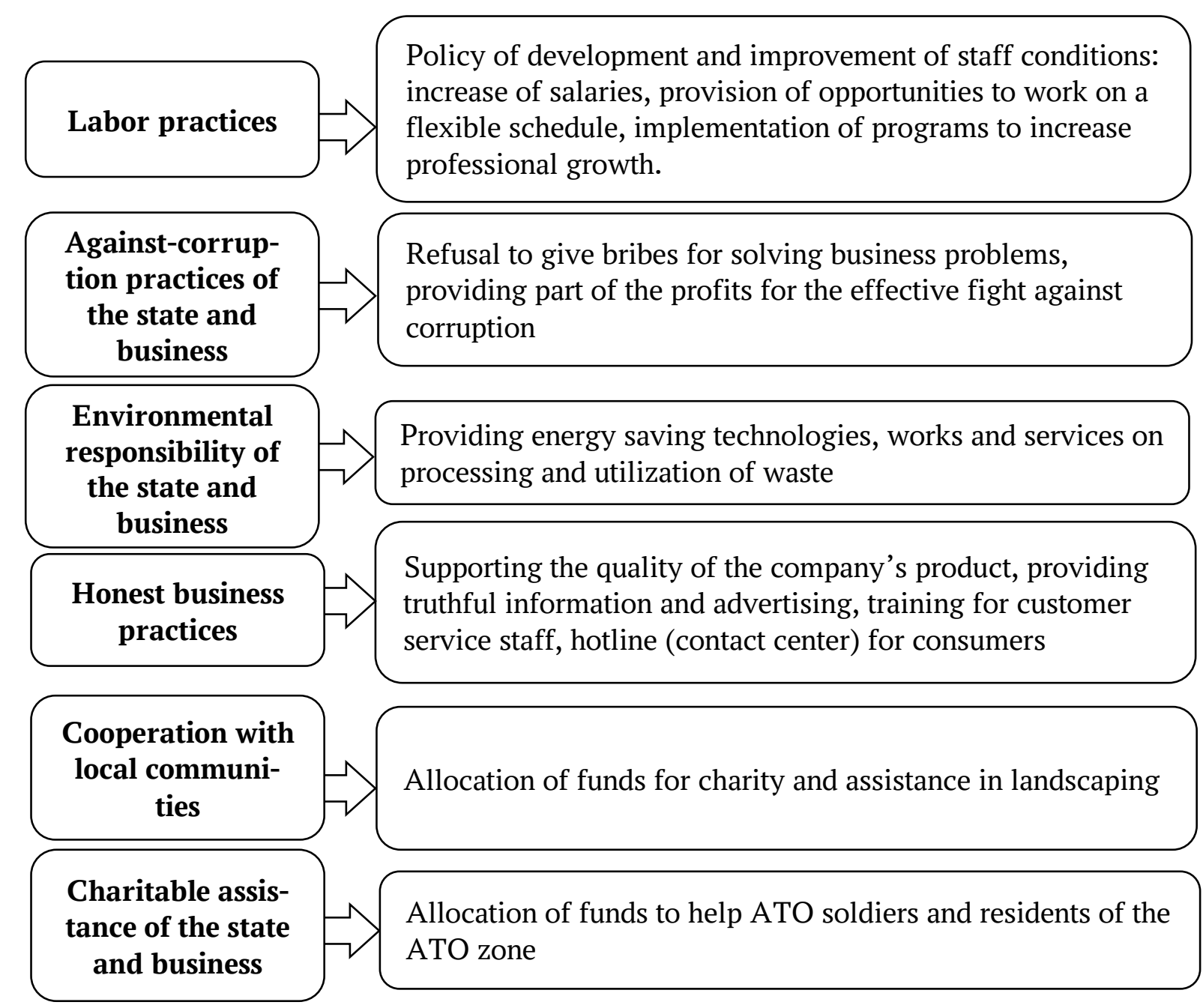

Fig. 1. The most common practices of implementing business social responsibility in Ukraine

Source: compiled by the authors.

From the aforementioned practices of implementing business social responsibility the basic directions of its realization in Ukraine are: policy of development and improvement of conditions of the personnel $-76 \%$, charitable help - 51\%, the help to soldiers of againstterrorist operation and residents of the againstterrorist operation zone $-30 \%$ (Zinchenko and Saprykina, 2018).

There is also an increase in the share of companies that provide assistance to local communities and make social investments in comparison to 2010 . Almost $60 \%$ of the surveyed companies help in the development of local communities. However, every fifth company in Ukraine does not help in the development of local communities (Zinchenko and
Saprykina, 2018). The most common directions of community assistance are the allocation of funds for charity and assistance in landscaping. In recent years, landscaping has also been the most common direction of community assistance. Most often, the region's presence in the North does not help (Zinchenko and Saprykina, 2018). They mainly provide various assistance to local communities in the East of the country, especially local authorities in the implementation of various social programs, are engaged in landscaping, provide jobs for displaced persons, help in the implementation of environmental projects.

\section{Conclusions.}

It is substantiated that the purpose of managing the relations of business social 
responsibility is the redistribution of social responsibility between the state and business entities in the direction of increasing the social responsibility of business structures. This goal is realized through the influence of the state on the improvement of labor relations, the implementation of honest business practices, against-corruption practices, expanding environmental responsibility and cooperation with local communities.

It is substantiated that Ukraine has not yet formed its own model of business social responsibility. It is determined that business social responsibility is gradually becoming an important component of strategic management of enterprises in Ukraine. However, in most cases, business social responsibility is limited to charity, and social investment is small. Important trends in the development of business social responsibility in Ukraine are insufficient assessment of the importance of social responsibility, and compliance with only mandatory rules set by applicable law.

As a result of the analysis of different types of relations between the state and business in the process of development of its social responsibility, it is established that in modern conditions the partnership relations of the state and business prevail (combined regulation), as well as there is an intensification of the development of self-regulation, which together are able to ensure their effectiveness in modern conditions.

\section{References}

Bondaruk, T. H. and Bondaruk, I. S. (2020), “The economic nature of the organizational and economic mechanism of social responsibility of business", Scientific Bulletin of the National Academy of Statistics, Accounting and Auditing, no. 1-2, pp. 57-64. doi: https://doi.org/10.31767/nasoa.1-2.2020.06

Friedman, M. (1970), "The social responsibility of business is to increase its profits", in: Zimmerli, W. C., Holzinger, M. and Richter, K. (eds) (2007), Corporate ethics and corporate governance, Springer, Berlin, Heidelberg, FRG, pp. 173-178. doi: https://doi.org/10.1007/978-3-540-70818-6 14

Gunningham, N. (ed.) (2009), Corporate environmental responsibility, Routledge, London, Great Britain, 628 p. doi: https://doi.org/10.4324/9781315259277

Hayek, F. A. (1967), “What's social? What does it mean?”, in: Hayek, F. A. (ed.) (1967), Studies in philosophy, politics and economics, Simon \& Schuster, New York, USA, pp. 237-247.

Komarova, K. V. and Kovalchuk, N. V. (2016), "Social responsibility as a component of business development strategy at the enterprises of Ukraine", Innovative Economy, no. 5-6, pp. 25-30.

Kovalenko, E. V. (2016), “Assessing the state of business social responsibility management”, Bulletin of SSU. Series: Economics, no. 3, pp. 27-39.

Lee, L. T-Sh. (2012), “The pivotal roles of corporate environment responsibility” Industrial Management \& Data Systems, vol. 112, issue 3, pp. 466-483. doi: https://doi.org/10.1108/02635571211210077

Socially responsible business. Ukraine (2020), “The strategy for promoting development of corporate social responsibility in Ukraine for the period till 2020”, available at: http://svb.ua/sites/default/files/201309 strategiya_spriyannya rozvitku_svb_v_ukrayini.pdf (Accessed 20 January 2020).

Yuzyk, L. O. (2010), “Approaches to assess the impact of CSR on the indecies the enterprise activities”, Bulletin of Mykhailo Tuhan-Baranovsky Donetsk National University of Economics and Trade. Series: Economic Sciences, no. 3, pp. 158-165.

Zinchenko, A. and Saprykina, M. (2017), Rozvytok KSV v Ukraini: 2010-2018 [CSR development in Ukraine: 2010-2018], Yuston, Kyiv, Ukraine, 52 p.

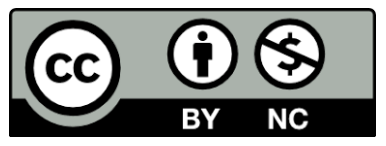

Цей твір ліцензовано на умовах Ліцензії Creative Commons «/з Зазначенням Авторства - Некомериійна 4.0 Міжнародна» (CC BY-NC 4.0). This is an open access journal and all published articles are licensed under a Creative Commons "Attribution-NonCommercial 4.0 International" (CC BY-NC 4.0). 